\title{
Evaluation of antihistaminic Activity of herbal drug isolated from Cuscuta reflexa Roxb.
}

Firdous A. Mala and Mushtaq A. Sofi

Department of Botany Govt. Degree College Handwara Jammu \& Kashmir, India 193221.

Received: 9/30/2017; Accepted: 10/16/2017

\begin{abstract}
The aim of present study was to find out the herbal drug which has potential antihistaminic properties. The ethnolic extract of cuscuta reflexa was found quite useful in showing anti histaminic activities, when tested on experimental albino rats. The rats were divided into four groups of two animals each. Group I was served as control and received water with ad-libitum but not treated and sacrificed for the observation of mast cells which were found $15.50 \pm 2 \%$ intact and $88.20 \pm 2 \%$ disrupted. In the II group which was treated with ethnolic extract of Cuscuta reflexa, it was noticed that when the dose of $50 \mathrm{mg} / \mathrm{kg}$ body weight were given orally with water, the disruption of mast cells was found $35.60 \pm 2 \%$ disrupted and intact mast cells were found $64.40 \pm 2 \%$. In the III group dose of $100 \mathrm{mg} / \mathrm{kg}$ body weight, the disruption of mast cells was found $27.70 \pm 2 \%$ and intact mast cells were found $72.30 \pm 2 \%$. The rats of group IV received $10 \mathrm{mg} / \mathrm{kg}$ of prednisolone (reference drug) orally for 4 days.
\end{abstract}

Keywords: Mast cell stabilization, Cuscuta reflexa, Photochemical, Antihistaminic, Asthma

\section{Introduction}

Mast cells are the group of connective tissues which show close relationship of histamine. Histamine secreted by the mast cells play important role in the inflammatory reaction in the body. He termed them plasma cells. Mast cells are immune systems (Watchman) spread across the body and have been used to test for newer agents against allergic disorders and chronic bronchial asthma (Barnes, 1993). The influence of natural products derived from plants is broadly recognized for their great structural diversity as well as their wide range of pharmaceutical activities (Mukherjee 2001). Since time immemorial the Adivasi of Kashmir valleys have been used local flora for their elements. The Cuscuta reflexa Roxb is mostly utilized by the local herbalists (Hakims) for cough cold and asthma. Cuscuta reflexa belongs to family Cuscutaceae and is a parasitic plant commonly known as Kokli port. The medicinal uses and chemical constituents of Cuscuta reflexa have been widely studied by Sharma et al., (2009). The Cuscuta reflexa has been investigated for antispasmodic, antisteroidogenic (Gupta et al., 2003) antihypertensive, muscle relaxant, cardio tonic (Singh et al., 1973) and anticonvulsant activities (Gupta et al., 2003). Many chemical constituents have been isolated from the Cuscuta reflexa such as g, amarbelin, beta- sterol, sigmasterol, myrecetin, quercetin and olenolic acid. (Mohammad Ali 2004) Considering the available information and folklore use of the plant, the present study was designed to evaluate the antihistaminic / mast cell stabilizing activity of ethnolic extract of whole plant material of Cuscuta reflexa.

\footnotetext{
${ }^{*}$ Corresponding Author:

Dr. Firdous A. Mala,

Deptt. Of Botany, Govt Degree College,

Handwara Jammu \& Kashmir-193221, India.

E-mail: firdousbotany9@gmail.com

\section{Materials and Methods}

Cuscuta reflexa Roxb. Was collected from the Baramulla district of Kashmir valley and was traditionally used for cough, cold and asthma by the tribal Gujjar and Bakerwals of that region. The whole plant was identified and authenticated from the Centre of Biodiversity and Plant Taxonomy University of Kashmir ( $\& \mathrm{~K}$ ). The herbarium of the plant has been deposited and the voucher specimen is procured in the Herbarium Record of Pest control and Ayurvedic Drug Research Laboratory S.S. L. Jain College Vidisha at Serial Number 37.

\section{Preparation of extract}

The air dried whole plant material of cuscuta reflexa $(500 \mathrm{~g})$ was reduced to coarse powder and subjected to extraction with ethanol in soxhlet extractor. The extract was concentrated to dryness on water bath to yield ethanol extract of Cuscuta reflexa.

\section{Animals}

The study was conducted on male albino rats of Wistar strain (Rattus norvegicus). The rats (150200gms) were obtained from the animal house of Pest Control and Ayurvedic Drug Research Laboratory, S.S.L. Jain College Vidisha (M.P.). The experimental work was carried out under the supervision of IAEC as per the guidelines of CPCSEA with the approval No. 804/03/CA/CPCSEA maintained under controlled conditions at temperature of $22 \pm 2^{\circ} \mathrm{C}$, humidity $60 \pm 10 \%$ and a $12 \mathrm{~h}$ light/dark cycle. They had free access to standard rodent pellet diet (Golden Feeds Private Ltd., Badodara) and water ad-libitum. 
Horse serum were procured from Himedia laborites, Mumbai, DPT antigen which contain Bordetella pertussis from Serum Institute of India, Pune, toludine blue from Lobachemie, Mumbai and prednisolone $10 \mathrm{mg}$ (I.P.), Wyeth limited, Goa. Other chemicals and regents were procured from Merck Mumbai.

\section{Preliminary Phytochemical Testing}

The standard phytochemical tests were used in screening the extract for different constituents.

\section{Test for flavonoids}

Alkaline Reagent test: In the test sample (ethnolic extract) a few drops of $\mathrm{NaOH}$ solution were added, immense yellow color was formed which turns colorless on addition of a few drops of acid. This indicates the presence of flavonoids in the extract.

\section{Tes for glycosides}

Cardiac glycosides:

Keller-Killiani test (Test for deoxy sugers): The sample was extracted with chloroform and evaporated with dryness and then $0.4 \mathrm{ml}$ of glacial acetic acid was added containing trace amount of ferric chloride. It was transferred to a small test tube and $0.5 \mathrm{ml}$ conc. $\mathrm{H}_{2} \mathrm{SO}_{4}$ was carefully added by the side of the test tube. Acetic acid layer showed blue color.

\section{Saponin Glycosides (Presence of saponin)}

Froth formation test: Two $\mathrm{ml}$ solution of crude ethnolic extract of Cuscuta reflexa was mixed in $7 \mathrm{ml}$ of distilled water in a test tube and shaken well, stable froth (foam) was formed, which showed the presence of saponin in the test sample.

\section{Test for steroids and tri-terpenoids}

Salkowski test: The ethnolic extract of Cuscuta reflexa was treated with a few drops of conc. $\mathrm{H}_{2} \mathrm{SO}_{4}$, yellow color at lower layer indicated the presence of triterpenoids.

Evaluation of mast cell stabilizing activity Active anaphylaxis

Male albino rats were weighed and randomly selected. All rats were sensitized by injecting subcutaneously $0.5 \mathrm{ml}$ of horse serum along with $0.5 \mathrm{ml}$ of triple antigen containing 20,000 million Bordetella pertussis organisms (Gupta et.al., 1973). The sensitized rats were divided into four groups. Group I received water and served as control. The rats of group II and III were orally administered with herbal extract of 50 and $100 \mathrm{mg} / \mathrm{kg}$ body weight respectively for the same duration. The rats of group IV received $10 \mathrm{mg} / \mathrm{kg}$ of prednisolone (reference drug) orally for 4 days. On the $14^{\text {th }}$ day 25 hours after the last dose of treatment rats were sacrificed and intestinal mesenteries and trachea were taken for the study of mast cells. Mesenteries of sacrificed rats were kept in Ringer-Locke solution $\left(\mathrm{NaCl} 9.0, \mathrm{KCl} 0.42, \mathrm{CaCl} 0.24, \mathrm{NaHCO}_{3}\right.$ 0.15 and glucose $1.0 \mathrm{gm} / 1$ of distilled water) at $37^{\circ}$ C. The mesenteric pieces were then shifted to a beaker containing 5\% horse serum distilled in Ringer-Locke Solution. After an incubation period of 10 minutes, the tissues were removed, trimmed and stained with 1.0\% toluidine blue solution and examined microscopically for the number of intact and de-granulated mast cells. A mast cell was considered disrupted if four or five granules were observed around the mast cells as reported by Norton (1954).

\section{Mast cell staining}

Pieces of intestinal mesenteries were mounted on slides. All slides were air dried, then stained with $1.0 \%$ Toluidine blue at room temperature for 5 minutes. Mast cells were readily identified by their metachromatic cytoplasmic granules under the light microscope.

\section{Statistical Analysis}

The results were expressed as mean \pm SEM and analyzed statistically using student t-test to find out the level of significance.

\section{Results and Discussion}

\section{Preliminary Phytochemical Screaning}

Preliminary phyto-chemical study of ethnolic fraction revealed the presence of flavonoids, cardiac glycosides; saponin glycosides steroids and triterpenoids table 1 .

Table 1. Showing preliminary phytochemical screening of selected plant materials.

\begin{tabular}{cccc} 
& \multicolumn{1}{c}{ Presence of Components } & Name of the test performed & Cuscuta reflexa \\
\cline { 2 - 4 } & Flavonoids & Alkaline reagent test & ++ \\
Glycosides & Cardiac Glycosides & Keller-Killiani test & - \\
& Saponin Glycosides & Froth formation test & ++ \\
Steroids and triterpenoids & Salkowski test & ++ \\
\cline { 2 - 3 } & &
\end{tabular}

In the present study, anti-histaminic or mast cell stabilizing activity was evaluated using ethnolic fractions of Cuscuta reflexa in anaphylactic Wistar albino rats (Fig.1). In the present investigation group I was served as control and have received water with ad-libitum but not treated and sacrificed for the observation of mast cells which were found $15.50 \pm$

$2 \%$ intact and $88.20 \pm 2 \%$ disrupted. Mast cells were observed carefully and percentage of intact and disrupted mast cells were calculated (Fig.2, Graph 1 and table 2). In the II group which was treated with 
ethnolic extract, it was noticed that when the dose of $50 \mathrm{mg} / \mathrm{kg}$ body weight were given orally with water by using oral feeding tube needle, the disruption of mast cells were found 35.60 $\pm 2 \%$ disrupted and intact mast cells were found $64.40 \pm 2$ $\%$ (Fig.3, Graph 1 and table 2). In group III, the dose of $100 \mathrm{mg} / \mathrm{kg}$ body weight for the extract, the disruption of mast cells were found $27.70 \pm 2 \%$ and intact mast cells were found $72.30 \pm 2 \%$ (Fig. 4, Graph 1table 2). However, in the group IV the standard drug Prednisolone of $10 \mathrm{mg} / \mathrm{kg}$ body weight, the percentage of intact mast cells showed was $84.50 \pm 2 \%$ and disrupted was $20.40 \pm 2 \%$ (Fig 5, Graph 1 and table 2).

Table 2. Effect of active fraction of plant extracts on albino rats.

\begin{tabular}{|c|c|c|c|c|c|}
\hline \multirow{2}{*}{ Group } & \multirow{2}{*}{ Treatment } & \multirow{2}{*}{$\begin{array}{c}\text { Dose } \\
\text { (mg/kg b. w.) }\end{array}$} & \multirow{2}{*}{ Route of administration } & \multicolumn{2}{|c|}{ Mast cells de-granulation } \\
\hline & & & & Disrupted \% & Intact $\%$ \\
\hline I & Control Sensitized & -- & Not given & $88.20 \pm 2 \%$ & $15.50 \pm 2 \%$ \\
\hline II & $\begin{array}{l}\text { Treated with Cuscuta } \\
\text { reflexa extract }\end{array}$ & 50 & Orally & $35.60 \pm 2 \%$ & $64.40 \pm 2 \%$ \\
\hline III & $\begin{array}{l}\text { Treated with Cuscuta } \\
\text { reflexa extract }\end{array}$ & 100 & Orally & $27.70 \pm 2 \%$ & $72.30 \pm 2 \%$ \\
\hline IV & $\begin{array}{l}\text { Standard drug } \\
\text { Prednisolone }\end{array}$ & 10 & Intra muscular & $20.40 \pm 2 \%$ & $84.50 \pm 2 \%$ \\
\hline
\end{tabular}

$P$ value $0.05, *$ SEM

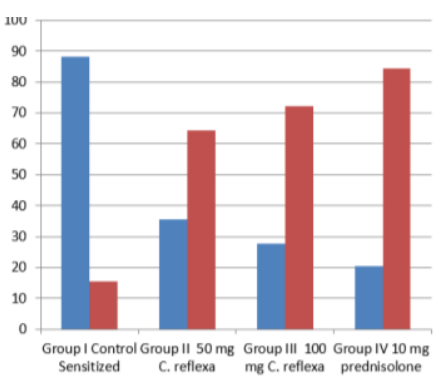

nisrupted mast cells
intact mast cells

Graph 1. Showing the percentage of intact and disrupted mast cells

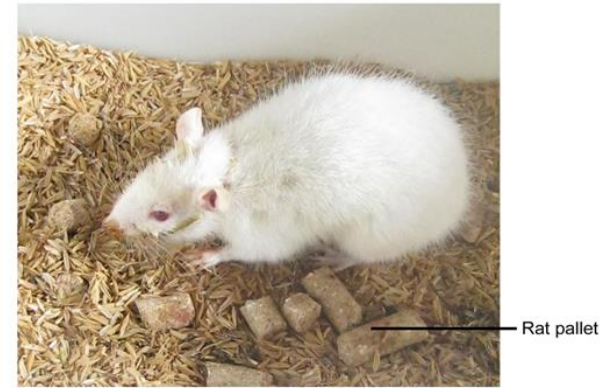

Fig.1 Experimental animal - Wistar albino rat.

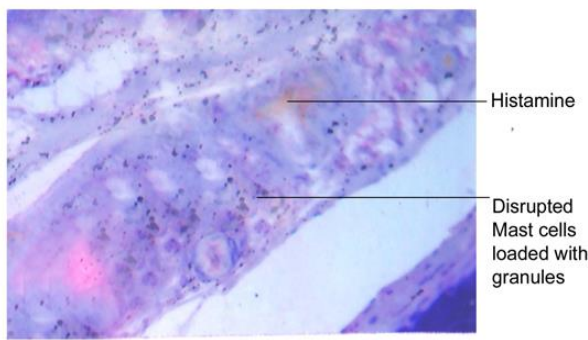

Fig. 2. Histopathology of mesenteries in sensitized control group of albino rats stained with Toluidine blue $\times 450$

Mast cells play a crucial role in the development of many physiological changes during allergic conditions of asthma. When the foreign particles come in to contact of mast cells, it trigger number of dramatic actions in the mast cells because they work as antigens. During dramatic actions mast cells release variety of chemicals like histamine that is a vasodilator which dilates blood vessels in the body.
Another is serotonin which constricts blood vessels. Heparin is a anticoagulant but it doesn't play role in asthmatic conditions. After histamine, leukotrienes and other substances also play important role in allergic and asthmatic conditions. However, body always develops immunity against antigen through increasing the production of antibody. Immunoglobulin $\mathrm{E}$ ( $\mathrm{IgE})$ is an antibody which always binds histaminic receptors on the surface of mast cells during asthma and allergy.

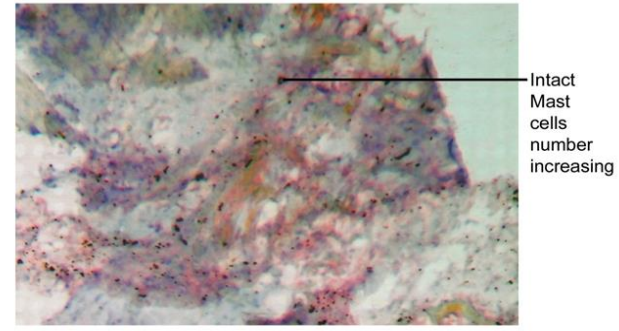

Fig. 3 Histopathology of mesenteries in treated group of albino rats when given $50 \mathrm{mg} / \mathrm{kg} \mathrm{b} . w$. dose of Cuscuta reflexa extract stained with Toluidine blue $X 450$

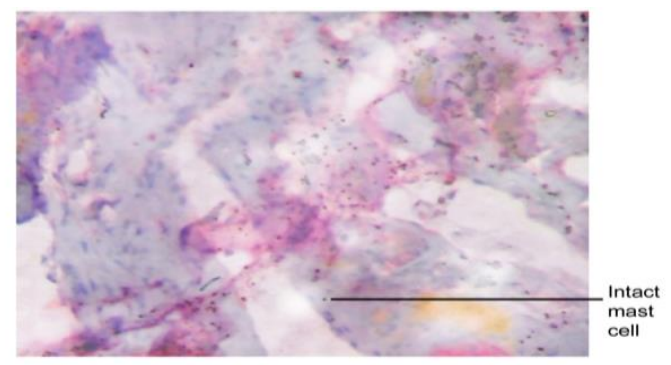

Fig.4. Histopathology of mesenteries in treated group of albino rats when given $100 \mathrm{mg} / \mathrm{kg} \mathrm{b}$.w. dose of Cuscuta reflexa extract stained with Toluidine blue $\times 450$.

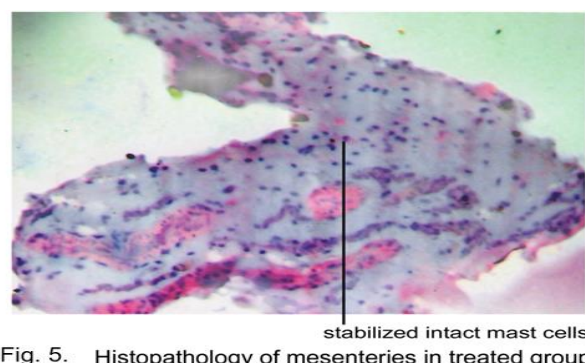

Fig. 5. Histopathology of mesenteries in treated group of rats wnen given $10 \mathrm{mg} / \mathrm{kg}$ b.w. dase of standard drug Prednisolone stained with Toluidine blue $\times 450$ 
The present study observed the influence of saponins and flavonoids treatment on the stabilization of mast cells. Chaudhary (2010) have reported such activity in Ocimum sanctum leaf extract. Mast cells are evenly distributed in mesenteries in trachea. They have been found to display abundant granules which can be clearly seen by the present author by using toludine blue staining which gave metachromatic cytoplasmic granules.

Mast cells de-granulation was seen with numerous extruded granules both near and the distance from the cell body. A thorough microscopic examination of mast cells in the treated animals was observed in the present study. In intact cells, granulation was seen after the treatment of extracts of Cuscuta reflexa. These mast cells were more immune reactive and granules were found to be distributed outside the cell body. De-granulated cells contain less prenuclear granule. Near the de-granulated cells, numerous collagen fibers were found. Similar observations have been carried out earlier by Soni et al., (2004), where they have described the mast cells de-granulation activity in the methanolic extract of Tephrosia purpurea. In the present investigation, evaluation of antihistaminic activity was carried out using a traditionally important plant of Kashmir valley. The animal treated with Cuscuta reflexa ethnolic extract at $100 \mathrm{mg} / \mathrm{kg}$ body weight showed $72.30 \%$ intact mast cells, which is quite comparable with the standard drug prednisolone $(84.5 \%)$ as shown in (Graph 1 and Table 20). Thus, the results of the present study clearly suggest an antihistaminic activity in the formulation of Cuscuta reflexa ethnolic extract. Sunilson et al., (2010) have also reported mast cells stabilizing activity of the cough syrup where they suggested that this may be attributed to the presence of plant phytoconstituents.

Preliminary phytochemical screening of the selected plant extract was done by using various chemical tests and it was reported that alkaloids, flavonoids, saponin glycosides, steroids and triterpenoids were found to be strong positive in the Cuscuta reflexa. Similarly, Sharma et al., (2009) have studied Cuscuta reflexa for preliminary phytochemical screening which revealed the presence of steroids, saponins, triterpenes and flavones in Cuscuta reflexa.

\section{Conclusion}

The present study provides evidence for the mast cell stabilizing activity of ethnolic extract of Cuscuta reflexa in experimental animals, which may be do to presence of flavonoids, and saponins. The need of the hour is to identify and isolate the phytoconstituents responsible for the observed central effects in animals and to understand their molecular mechanism.

\section{Acknowledgement}

The authors are thankful to the Curator of Biodiversity and Plant Taxonomy University of Kashmir (J \& K) for their identification and authentication of the plant material.

\section{References}

1. Chaudhary G.P. (2010). Mast cells stabilizing activity of Ocimum. Sanctum leaves. Inter. J. Pharma and Biosciences. 2010; 1 (2): 1-11.

2. Gupta M, Mazumdar UK, Bhattacharya S, Chakrabarty S. Studies on brain biogenic amines in methnolic extract of Cuscuta reflexa Roxb and Corchorus alitorius Linn seed treated mice. Acta Pol Pharma, 2003;60 (3), 207-10.

3. Gupta M, Mazumdar UK, Pal DK, Bhattacharya S (2003). Anti-steroidogenic activity of methnolic extracts of Cuscuta reflexa stem and corchorus alitorius Linn. seed in mouse ovary. Ind.J.Exp. Biol. 2003; 41 (6), 641.

4. Mohammad Ali V., Studies in the chemical constituents of Bombax ceiba and Cuscuta reflexa Acta. Pol. Pharm., 2004; 60(3), 207-210.

5. Mukherjee Pk. Evaluation of Indian traditional medicine. Drug information J., 2001; 35:623-632.

6. Norton S. Quantitative determination of mast cell fragmentation by compound 48/80. Br. J. Pharmacol. 1954. 2:484.

7. Sharma S., Hullatti K.K., Prasanna S.M., Kuppast I.J. and Sharma P. Comparative study of Cuscuta reflexa and Cassytha filiformis for diuretic activity. Pharmacongosy Magazine, 2009; 1 (5): 327-330.

8. Singh GS and Garg KN. Some Pharmacological studies on Cuscuta reflexa plant, Ind. J. Pharmacog. 1973; 35 (2), 344 45 .

9. Soni Kapil. K., Khare M.L. and Saxena R.C. Spasmolytic activity of a herbal drug isolated from Tephrosia purpurea in guinea pigs. 2004; 23(4): 1-6.

10. Sunilson, J.A. J., Anandrajgopal K., Khan A., Pasha K., Hassan Q.B. and Kuna Raja P.V. (2010). Antihistaminic evaluation of formulated polyherbal cough syrup. J. Medicinal Plants Res. 2010; 4 (14): 1482-1485.

\section{Cite this article as:}

Firdous A. Mala and Mushtaq A. Sofi. Evaluation of antihistaminic Activity of herbal drug isolated from Cuscuta reflexa Roxb. Annals of Plant Sciences 6.11 (2017) pp. 1807-1810.

Doi: http://dx.doi.org/10.21746/aps.2017.11.15 